\title{
THIN-FILM SILICON SOLAR CELLS ON FLEXIBLE SUBSTRATES
}

\section{Andrey G. Kazanskii}

Lomonosov Moscow State University, Department of Physics, http://www.phys.msu.ru

119991 Moscow, Russian Federation

kazanski@phys.msu.ru

Abstract. Advances in the design and creation of thin film solar cells have led to the development of a trend in photovoltaics - photovoltaic of "flexible" solar cells, namely thin-film solar cells formed on flexible substrates. Possibility of changing the form of these solar panels opens up new possibilities for their application, in particular, for energy supply of mobile, portable electronic devices. Such solar cells may be mounted on objects having a complex, not a smooth surface, including clothing. In addition, the relative simplicity of the process of creating such solar cells, low power consumption and low cost of flexible substrates used reduce significantly the cost of their production. Protocrystalline hydrogenated silicon is one of the leading among various semiconductor materials used for creation of "flexible" solar panels. The structure of this material is composed of an amorphous silicon matrix having nanocrystalline inclusions. This paper presents a review of available data on the properties of hydrogenated silicon films, the conditions of protocrystalline hydrogenated silicon production and parameters of flexible solar cells based on this material.

Keywords: solar cells, thin films, amorphous silicon, nanocrystalline silicon, protocrystalline silicon.

PACS: 68.55.ag; 72.40.+w; 77.55.df; 88.40.jj

Bibliography - 50 references

Received 25.02.2015

RENSIT, 2015, 7(1):15-24

DOI: $10.17725 /$ rensit.2015.07.015

\section{Contents}

1. INTRODUCTION (15)

2. Selection of the optimal UNDOPED LAYER TO FORM A SOLAR CELL ON FLEXIBLE SUBSTRATES (17)

3. Formation OF THE DOPED LAYERS FOR SOLAR CELLS ON FLEXIBLE SUBSTRATES (19)

4. Formation of SOLAR CELLS ON FLEXIBLE SUBSTRATES (19)

5. Conclusions (21)

References (21)

\section{INTRODUCTION}

In recent years there has been a significant increase in interest in solar cells on flexible substrates ("flexible" solar cells) and, accordingly, the number of papers devoted to a study. Although flexible substrates include stainless steel foil and plastic, however, in most cases, speaking of the "flexible" solar cells have a mean solar cells formed on a flexible plastic. On the one hand, marked interest stems from the fact that such batteries have a small thickness and, accordingly, light weight, which facilitates the delivery of their use in those places where it is difficult to deliver solar cells formed on heavy glass substrates [1]. On the other hand, such solar cells can be attached to objects having a complex, not a smooth surface, including clothing [2]. The low cost, simplicity and light weight of solar cells on flexible substrates, according to some researchers, making them attractive for a variety of energy facilities operating in outer space.

The comparative cheapness of solar cells formed on flexible substrates, as compared to solar cells on glass, associated primarily with the possibility of their production by so-called method "from roller to roller" (roll-to-roll method). In addition the reduction of energy consumption in creating solar cells on flexible substrates in comparison with batteries formed on the glass is related to the use of plastic substrates that do not require essential energy during their formation. Therefore, despite the 
fact that in recent years the production of thinfilm silicon solar cell formed on $\sim 6 \mathrm{~m}^{2}$ glass substrate has increased [3, 4], there is need for new approaches to the creation of solar cells that enable to considerably increase productivity in production lines with significantly reducing costs. A method of roll coating, which in recent years has been used successfully [5] and investigated in detail $[6,7]$, apparently, is one possible approach, allowing to solve the problem set forth above. However, to compete with the "large area" photovoltaics formed on the glass plates, the production method of photovoltaic modules based on the "roll coating" should solve a number of problems associated with a decrease in the cost of the substrate, technological simplicity and low cost of solid encapsulation. Taking into account the importance of all of the above problems associated with the production of "flexible" solar cells, we consider below the problems associated with low-temperature deposition and the formation of a successive structure of the solar cell. Note here that the encapsulation process also requires the study and currently adds $50 \%$ to the value of the "flexible" solar module [8]

In addition to the applications associated with the creation of networks, in particular, photovoltaic integrated into buildings, the interest to photocells on flexible substrates increases with the development of autonomous systems and orbital stations of telecommunications satellites, as well as professionals working in the field of rural electrification in developing countries. Small airplanes, cars and other electricity consumers can get their part of the necessary energy from the ambient illumination of the exposed surfaces using flexible solar cells. Another application of "flexible" photovoltaics is to integrate photovoltaic systems in small sizes in clothing to power portable electronic devices $[2,9,10]$. More broadly speaking, the creation of technology for integration of photovoltaic systems with a flexible textile material can be used for covering buildings and provide an autonomous control of heating, ventilation and lighting of the building.

It should be noted that "flexible" PV based on amorphous silicon have been laid by Izu and Ovshinsky in 1984 [11], when they offered to form a thin-film solar modules by «roll to roll» method on rolls of stainless steel foil. This technology led further to the creation of the "roll coating" method [5, 12]. In 1985 Jeffrey and co-workers introduced first flexible solar cells based on a-Si, formed on a polyimide (PI) and discussed the fundamental problems associated with substrate thermal expansion and impurity control [13]. These issues remain unresolved to this day. Yano and co-workers in 1987 formed a-Si solar cell on a polyethylene terephthalate (PET) substrate with 9\% efficiency using the "roll-to-roll" method [14]. More recently, Haug and co-workers reported the creation of a single-cell a-Si solar cells on nanostructured PET with stabilized conversion efficiency of $8.7 \%$, as well as the formation of a two-part, a tandem, so-called micromorph solar cell composed of $a$-Si element made on the surface of the microcrystalline element with conversion efficiency of $10.9 \%$ [15]

Currently, "flexible" photovoltaic cells were developed, which do not use technology based on $a$-Si. In particular, there are reports on flexible solar cells based on monocrystalline silicon with a conversion efficiency of 14.6\% [9]. It should be noted that the parameters of optimized solar cells based on single crystal silicon exceed parameters of elements based on $a-S i$ in the illumination intensity from medium to low level due to the greater efficiency of conversion. At the same time at a very low level of less than 500 lux solar cell based on $a-S i$ is superior solar cell based on $c-S i[2,16]$. The conversion efficiency of flexible solar cells based on copper indium gallium diselenide (CIGS), formed on the stainless steel foil, reaches efficiency of $17.4 \%[17,18]$ At the same time, the conversion efficiency of cells based on CIGS, formed on PI substrates at low deposition temperature is 
reduced to $11 \%$ [18-20]. Tiwari and co-workers reported the creation of flexible solar cells based on $C d T e$ with a conversion efficiency of 8.6\% [21]. Besides it seems promising flexible solar cells, based on organic semiconductor and the so-called solar cells sensitized with dyes. This type of battery can be applied by printing on a polymer foil [22]. An example of some progress in the area of organic solar cells is the representation made by Brabec and co-workers on the bulk heterojunction battery with a conversion efficiency of 5\% [23]. Major problems when creating organic solar cells and solar cells, used the dyes, is the need to increase the absorption of visible light by layer to increase the sensitivity [22] and photochemical stability of dyes [24]. The most important problem is the durability of the use of organic solar cells [25].

Apart from the need to optimize the material and structure of the solar cell in the case of flexible substrates it is necessary to solve the problems associated with series connection of individual solar cells in photovoltaic module [1]. Monolithic series connection of individual elements increases the power of photovoltaic modules for cheap photovoltaic systems [26]. Commonly used laser scribing technique has been used successfully for the elements formed on the high-temperature glass substrates. At the same time, this technology meets many problems in the case of its use to create panels on flexible polymer foils, resulting in an increase in the width of the incision, as well as problems associated with bypass surgery. Therefore, a technique of coupled elements using masks directly during different stages of deposition has been proposed [27, 28].

Authors of [1] presented the results of studies on optimization of low-temperature deposition of solar cells based on hydrogenated silicon and consisting of amorphous hydrogenated silicon ( $a-S i: H)$, nanocrystalline silicon ( $n c-S i)$ and protocrystalline silicon ( $p c$ Si). In the same paper, the authors developed a technique for formation of cells in series in situ, which allows to avoid the technology of laser scribing and interrupting the deposition process in a vacuum.

The authors of [1] studied the solar panels made from optimized solar cell using the pc-Si, deposited on a flexible cheap polymer substrate at substrate temperatures of $40^{\circ} \mathrm{C}<T_{d}<110^{\circ} \mathrm{C}$. Experiments have shown that in the case of nontextured PET foil for the substrate temperature of $T_{d}=110^{\circ} \mathrm{C}$ the conversion efficiency was $9 \%$ [29]. Solar module with the area of $4 \times 10 \mathrm{~cm}^{2}$ that used a single-cell $a$-S $i$ pin structure and formed on a polyethylene naphthalate (PEN) demonstrates a conversion efficiency of $3 \%$ [27].

\section{SELECTION OF THE OPTIMAL UNDOPED LAYER TO FORM A SOLAR CELL ON FLEXIBLE SUBSTRATES}

It is assumed that an optimum material for absorbing layer of silicon solar cell is protocrystalline undoped silicon (pc-Si) [30], which is superior in electronic parameters compared to a-Si and nc-Si. Pc-Si is the only best material when using low substrate temperatures $T_{d}<100^{\circ} \mathrm{C}$ for producing thin-film solar cells based on $S i$ [31]. At the same time, if $T_{d}>200^{\circ} \mathrm{C}$ the parameters of the solar cell is improved by the transition from $a-S i$ to $p c-S i$ when forming a light-absorbing layer [32]. Protocrystalline silicon is a material which is formed at the process conditions at the transition boundary for forming of $a$-Si and $n c-S i$. Therefore, its structure consists of amorphous silicon matrix containing discrete inclusions of nanocrystalline silicon. Thus, the volume fraction of nanocrystalline phase $X_{C}$ in $p c-S i$ is close to zero contrast to the nc-Si.

Protocrystalline silicon was the result of experiments on the optimization of the active layer of thin film cells based on Si and SiGe [32], which led to the creation of structurallymodified material called protocrystalline silicon [30]. Review of the structural properties of the material containing uncontrollable concentration of silicon nanocrystals, carried 
out in [33]. The primary goal in forming a solar cell based on the $p c-S i$ is to select the process conditions that can form silicon nanocrystals in the amorphous matrix which are not in contact with each other.

The formation and increase of nanocrystal concentration in material depends on the deposition temperature, the proportion of hydrogen in the hydrogen-silane, gas mixture and the film thickness [34, 35]. The result is determined by a rather narrow range of process parameters that provide a $p c-S i$ [36]. If the process does not use fluorinated or chlorinated gases [37], then, as a rule, the volume fraction of a nanocrystalline phase increases with the film thickness [34, 35, 38-41].

The formation of $p c-S i$ requires a large proportion of hydrogen in the gaseous medium using the method of plasma chemical vapor deposition (PECVD) or other gas-phase method (CVD), for example, thermal vapor deposition method (hot-wire CVD) [41-43]. The increasing of relative proportion of hydrogen in the hydrogen-silane gas mixture $\mathrm{R}=\left[\mathrm{H}_{2}\right]$ / $\left[\mathrm{SiH}_{4}\right]$ results in sharp change of optoelectronic material properties in the $R$ region from 15 to 50. The optimum value of $R$, needed to obtain $p c-S i$, depends on the substrate temperature $T_{d}$ and the geometry of the reaction chamber in which deposition of material takes place [44].

The dependence on $R$ of optoelectronic properties of films obtained by PECVD at $T_{d}$ $=40^{\circ} \mathrm{C}$ and $T_{d}=75^{\circ} \mathrm{C}$ have been studied in [36] in order to analyze the properties of the film formation conditions, which allow the $S i$ deposition on flexible cheap PET substrate at low temperatures $\left(T_{d}<100^{\circ} \mathrm{C}\right)$. Pc-Si film forming in the transition region from $a-S i$ to the $n c-S i$ showed optoelectronic properties that are superior to the corresponding properties of $a-S i$ and $n c-S i$. The results are shown in Fig. 1. Measurements of photosensitivity (the ratio of photoconductivity to dark conductivity) were carried out under illumination of the films by light with photon energies $b v=1.96$

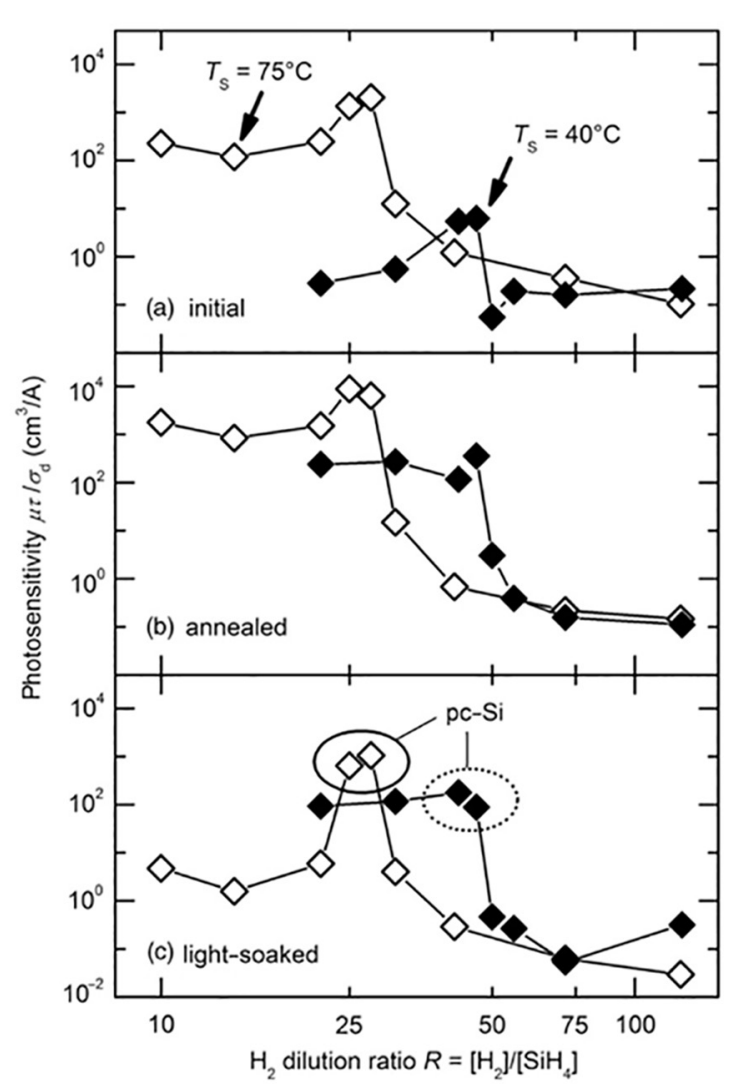

Fig. 1. Dependences of photosensitivity of the films made at $T_{d}=40^{\circ} \mathrm{C}$ and $T_{d}=75^{\circ} \mathrm{C}$ on $\mathrm{R}$. The data show the results of the measurements made immediately after preparation of the films (a) after film annealing at $110^{\circ} \mathrm{C}$ for 16 hours (b) after film illumination at $\mathrm{T}<50^{\circ} \mathrm{C}$ with light intensity of AM 1.5 for 100 bours (c) [1].

$\mathrm{eV}$ and intensity $1.3 \cdot 10^{15} \mathrm{~cm}^{-2} \mathrm{~s}^{-1}$. The thickness of the films was $\approx 1 \mu \mathrm{m}$. The rate of deposition of the films decreased significantly with increasing $R$.

As can be seen, the annealing results in an increase of photosensitivity of the films, due, apparently, to the redistribution of hydrogen in the structure of $a-S i$ and $p c-S i$. Thus films obtained at $R=29\left(T_{d}=75^{\circ} \mathrm{C}\right)$ and $R=45$ $\left(T_{d}=40^{\circ} \mathrm{C}\right)$, demonstrate not only the highest photosensitivity, but the best parameter stability under light exposure [45].

Koch and coworkers [31, 36, 46], and Ishikawa and Schubert [29] demonstrated that the creation of undoped $p c-S i$ at substrate temperatures of $40^{\circ} \mathrm{C}<T_{d}<110^{\circ} \mathrm{C}$ with good optoelectronic properties and photosensitivity (more then $10^{5}$ ) requires appropriate selection of $R$ and a plasma discharge with sufficiently high frequency. 


\section{FORMATION OF THE DOPED LAYERS FOR SOLAR CELLS ON FLEXIBLE SUBSTRATES}

The necessity of using low substrate temperatures $\left(T_{d}<100^{\circ} \mathrm{C}\right)$ in the case of forming a solar cell on a cheap flexible PET foil leads to some problems of obtaining doped layers, associated with low efficiency of doping $a$-Si at low temperatures [47]. The authors of [43] compared the parameters of $a-S i$ and $n c-S i$ films, obtained by method of high-frequency plasma chemical deposition and method of "hot wire" at substrate temperatures $T_{d}=25^{\circ} \mathrm{C}$ and $T_{d}=100^{\circ} \mathrm{C}$, and doped with donor ( $n$-type) or acceptors ( $p$-type). It was noted monotone change in the structure from amorphous to nanocrystalline with increasing $R$ in the case of "hot wire" method and a dramatic change in the structure in the case of "high frequency method". In addition there was a significant increase in the efficiency of doping of the films after annealing at $300^{\circ} \mathrm{C}$, resulting in increased of $a-S i$ films conductivity two orders of magnitude [48].

Koch found a significant reduction (four orders of magnitude) conductivity of $n$-type a-Si films when substrate temperature decreases from $T_{d}=150^{\circ} \mathrm{C}$ to $T_{d}=100^{\circ} \mathrm{C}$ in the case of high-frequency plasma chemical deposition method [31]. Studies have shown that the problem of high concentration of defects and low efficiency of doping can be overcome in the case of silane-hydrogen mixture with $R>3$ [31, 36]. Thus it is possible to raise the conductivity of the $n$-type film obtained at $T_{d}=100^{\circ} \mathrm{C}$, to a value $5 \cdot 10^{4} \mathrm{Ohm}^{-1} \mathrm{~cm}^{-1}$. Unlike the $n$-type material, in the case of $p$-type material the problem of obtaining doped $a$-Si or $p c-S i$ film at low substrate temperatures requires solutions.

Fig. 2 shows the results of measurements of the conductivity and photoconductivity of $n$ - and $p$-type films, made at low substrate temperatures, obtained by Koch and co-workers $[31,36]$, and Ishikawa and Schubert [29]. It was noted that the $p$-type film with high conductivity can be made only in the case of large plasma

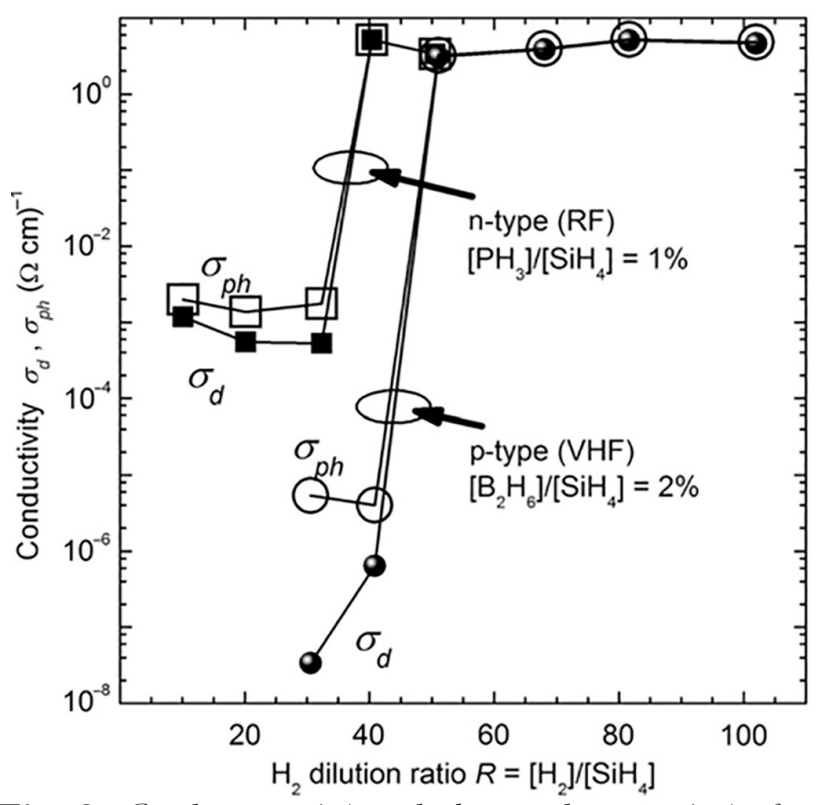

Fig. 2. Conductivity $\left(\sigma_{d}\right)$ and photoconductivity $\left(\sigma_{p b}\right)$ of $n$ and p-type films made at low substrate temperatures and at different $\mathrm{R}$ values [1].

discharge excitation frequencies (80 MHz). At the same time, a high conductivity $n$-type films could be made when using medium frequency of $13.56 \mathrm{MHz}$.

\section{FORMATION OF SOLAR CELLS ON FLEXIBLE SUBSTRATES}

Koch and co-workers showed [36], that $p c$ $S i$ as an active layer of the solar $p-i-n$ element gives the best parameters in the case of film deposition at low temperatures $\left(T_{d}<100^{\circ} \mathrm{C}\right)$. When $T_{d}=75^{\circ} \mathrm{C}$ conversion efficiency of obtained element was $3.8 \%$. At the same time, conversion efficiency of $6 \%$ was obtained for $T_{d}$ $=100^{\circ} \mathrm{C}$ [31]. After photo-induced degradation the conversion efficiency decreased somewhat and amounted $\approx 5 \%$ for structures formed at $T_{d}$ $=110^{\circ} \mathrm{C}[49]$.

Fig. 3 shows the correlation between photosensitivity and ambipolar diffusion lengths for the active layer formed of $p c-S i$ at a low temperature $T_{d}=110^{\circ} \mathrm{C}$ (Fig. 3a) and $p-i-n$ conversion efficiency of the solar cell, deposited on the substrate Asahi-U and using this film (Fig. 3b) [1]. The values are shown for $p-i-n$ element efficiency before and after the lighting for 100 hours of light with an intensity of AM 1.5. 


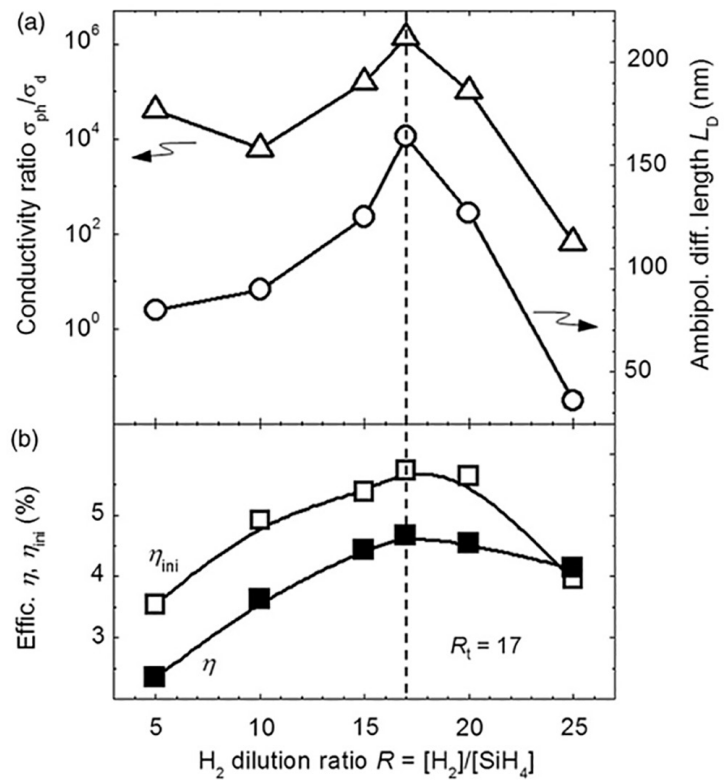

Fig. 3. The effect of $R$ on the photosensitivity and on the charge carrier ambipolar diffusion length of undoped bydrogenated silicon film made at a low substrate temperature (a), and on conversion efficiency of $p$-i-n solar cell before $\left(\eta_{\text {in }}\right)$ and after ( $\eta$ ) extended lighting (b) [2].

The ability to change the optical band width when changing $R$ allows to form multi-element solar cells at low temperatures [31, 46, 50]. Fig. 4 shows the current-voltage characteristics for two-element (tandem) and four-element solar cells formed on a flexible PET foil [1].

Koch and co-workers reported on creation of a "low-temperature" $p-i-n / p-i-n$ and $n$-i- $p / n-i-p$ solar cells with an initial (before light degradation) conversion efficiency of $6 \%$ [31]. Researching the effect of the sequence of formed layers on

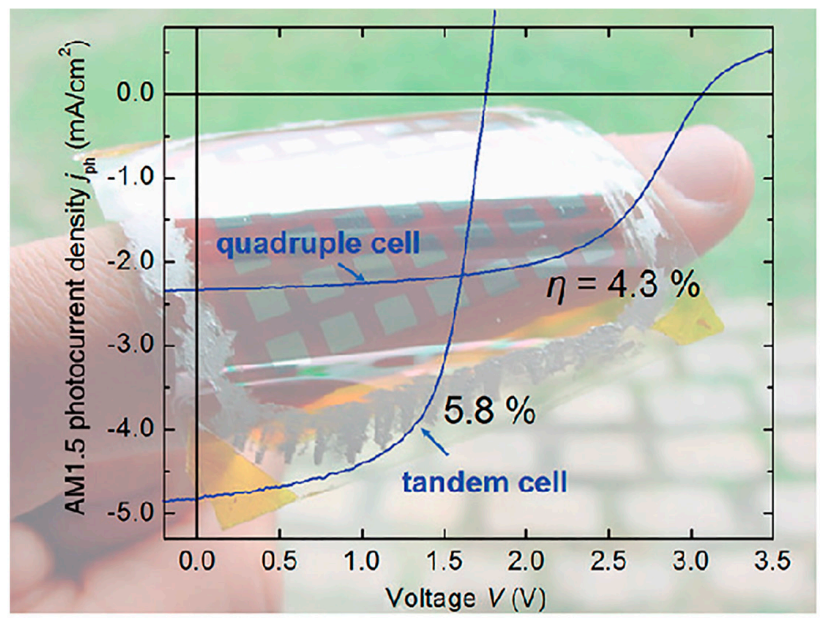

Fig. 4. Current-voltage characteristics of two-element and four-element solar cell formed on a flexible PET foil [1]. the stability of the structure parameters Ishikawa and Schubert showed that $n-i-p$ structure with a $p c-S i$ active layer is more stable under exposure to light [49].

Fig. 5 shows current-voltage characteristics obtained for a $p-i-n$ structure formed on glass substrate and $50 \mu \mathrm{m}$ PET foil substrate [1]. Both the solar cells with the area of $9 \mathrm{~mm}^{2}$ were formed under the same conditions. As can be seen, the conversion efficiency of the optimized "low temperature" solar cell formed on a PET foil is almost identical with the conversion efficiency of the element formed on the glass.

In the case of solar cells, integrated into clothing, the substrates of the solar cells must be sufficiently thin not to change significantly the "flexibility" of the material on which they are placed. Fig. $\mathbf{6 a}$ and $\mathbf{6} \mathbf{b}$ show an array of $p c-S i$ solar cells, formed on thin PET foil with the thickness of $23 \mu \mathrm{m}$. Since the thickness of the active layer of the battery is $1 \mu \mathrm{m}$, the mechanical strength of the battery is determined by PET foil. However, as can be seen from the figure, the solar battery follows the shape of the material to which it is attached. The conversion efficiency of shown solar cell is $5 \%$. Note that we also need to create a thin and durable material for

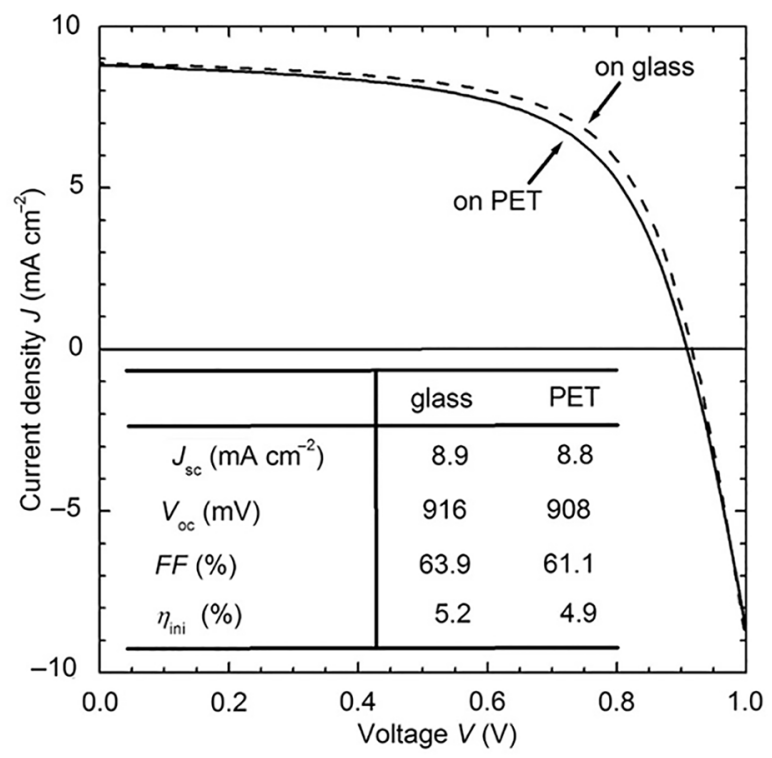

Fig. 5. Current-voltage characteristics of "low-temperature» p-i-n solar cells formed on glass and PET foil [2]. 


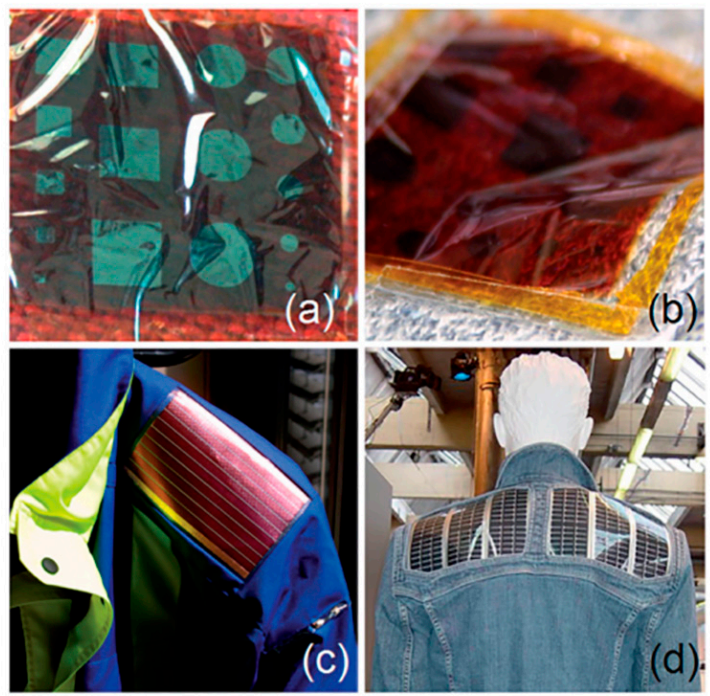

Fig. 6. Photo of solar cells based on pc-Si, formed on 23 um PET foil, looking at the Al back contacts (a), and showing the front view in the direction of the incident light.(b) and photographs of jackets with embedded in commercial solar battery on flexible substrates (c and d) [2].

encapsulation of solar cells. Fig. $6 \mathrm{c}$ and $6 \mathrm{~d}$ show examples of commercial photovoltaic modules, which are integrated in jackets to supply emergency LEDs (Fig. 6c), mobile phone, MP3 player and other electronic devices that use a standard USB connector (Fig. 6d) [2]. Fig. 7 shows estimated areas [2] which are needed to power these electronic devices using currently established various thin film solar cells on flexible substrates. The authors noted that as it is possible to integrate $1000 \mathrm{~cm}^{2}$ solar cell into adult clothing, flexible solar cells can provide the necessary power.

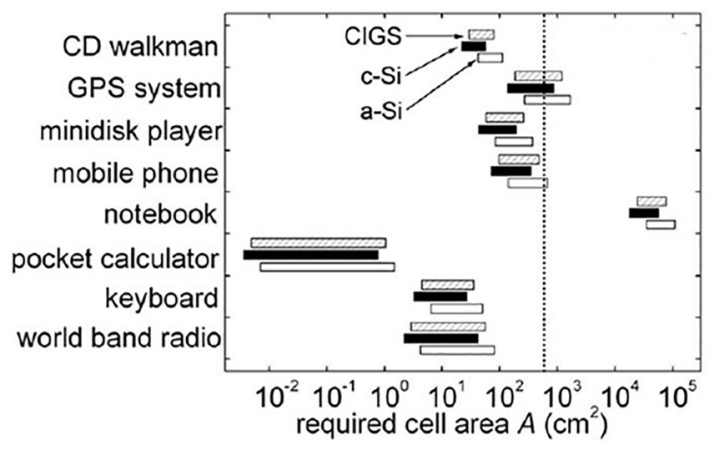

Fig. 7. Areas of "flexible" thin-film solar batteries, integrated into clothes, that are necessary to power electronic devices, indicated in the figure.

\section{CONCLUSION}

Review of the literature devoted to solar cells on flexible substrates shows that the use of flexible substrates (stainless steel foil or plastic foil) is somewhat easier and cheaper process of forming a solar cell, which is partly due to the possibility of using the "roll-to-roll" technique. The production of solar cells based on hydrogenated silicon films on flexible polymeric substrates requires development of the solar cells technology based on this material prepared at relatively low temperatures $\left(<150^{\circ} \mathrm{C}\right)$. A preferred material for forming the active layer in this case is protocrystalline hydrogenated silicon pc-Si:H, whose parameters depend strongly on the ratio of hydrogen-silane gas mixture and reactor design for deposition of films. Currently available silicon solar cells made on the nontextured PET foil at substrate temperature of $T_{d}=110^{\circ} \mathrm{C}$ show a conversion efficiency $\approx 5 \%$ [1]. The flexible solar battery, with an area of 40 $\mathrm{cm}^{2}$, consisting of 10 solar cells, demonstrates the conversion efficiency of $3 \%$. Studies show that there are opportunities to improve the conversion efficiency of these cells associated with a corresponding change of the structure of the layers forming the solar cell and the structure of the element.

\section{REFERENCES}

1. Schubert MB, Merz R. Flexible solar cells and modules. Phil. Mag., 2009, 89:2623-2644.

2. Schubert MB, Werner JH. Flexible solar cells for clothin. Materials Today, 2006, 9:42-50.

3. Tanner D, Mei F, Le M, Su J, Luu C, Lu W, Frei M, Prabhu G, Chae YK, Eberspacher C. Fabrication and performance of large area thin film solar modules. Proc. of the $23 \mathrm{rd}$ European Photovoltaic Solar Energy Conference. D. Lincot, H. Ossenbrink and P. Helm eds., WIP-Renewable Energies, Munich, 2008, p. 2489-2491.

4. Vetter M, Mata C, Andreu J. Lessons learned in production optimization of $2.60 \mathrm{~m} \times 2.20 \mathrm{~m}$ a-Si:H photovoltaic modules. Proc. of the $23 \mathrm{rd}$ 
European Photovoltaic Solar Energy Conference. D. Lincot, H. Ossenbrink and P. Helm eds., WIP-Renewable Energies, Munich, 2008, p. 2075-2078.

5. Guha S, Yang J. Thin film silicon photovoltaic - from R\&D to commercialization. Technical Digest of the 15th International Photovoltaic Scientific Engineering Conference PVSEC-15. Y. Quinhao ed., Shanghai Scientific \& Technical, Shanghai, 2005, p. 35-38.

6. Tanda M, Tabuchi K, Uno M, Kato S, Takeda Y, Iwasaki S, Yokoyama Y, Wada T, Shimosawa M, Sakakibara Y, Takano A, Nishihara H, Enomoto H, Kamoshita T. Large-area, light-weight, flexible solar cell production technology - ready for market entry. Conference Record of the 31st IEEE Photovoltaic Specialists Conference. IEEE, New York, 2005, p. 1560-1563.

7. Jongerden GJ. Monolithically series integrated flexible PV modules manufactured on commodity polymer substrates. Proc. of the 3rd World Conference on Photovoltaic Energy Conversion. Osaka, 2003, IEEE, p. 21092111.

8. Ballif C, Terrazzoni-Daudrix V, Haug F-J, Fischer D, Soppe W, Loffler J, Andreu J, Fahland M, Schlemm H, Topic M, Wurz M. Flexcellence: towards roll to roll mass production of low cost thin film silicon solar cells. Proc. of the 22nd European Photovoltaic Solar Energy Conference. G. Willeke, H. Ossenbrink and P. Helm eds., WIP Renewable Energies, Munich, 2007, p. 1835-1839.

9. Werner JH, Wagner TA, Gemmer C, Berge C, Brendle W, Schubert MB. Recent progress on transfer-Si solar cells at ipe Stuttgart. Proc. of the 3rd World Conference on Photovoltaic Energy Conversion. Osaka, 2003, IEEE, p. 1272-1275.

10. Schubert MB, Ishikawa Y, Kramer JW, Gemmer CEM, Werner JH. Clothing Integrated photovoltaics. Conference Record of the 31st IEEE Photovoltaic Specialists Conference, IEEE, New York, 2005, p. 1488-1451.

11. Izu M, Ovshinsky SR. Roll-to-roll plasma deposition machine for the production of tandem amorphous silicon alloy solar cells. Thin Solid Films, 1984, 119:55-60.

12. Yang J, Banerjee A, Guha S. Triple-junction amorphous silicon alloy solar cell with $14.6 \%$ initial and $13.0 \%$ stable conversion efficiencies. Appl. Phys. Lett., 1997, 70:29752977.

13. Jeffrey FR, Vernstrom GD, Aspen FE, Jacobson RL. Fabrication of amorphous silicon devices on plastic substrates. Mater. Res. Soc. Symp. Proc., 1985, 49:41-43.

14. Yano M, Suzuki K, Nakatani K, Okaniwa H. Roll-to-roll preparation of a hydrogenated amorphous silicon solar cell on a polymer film substrate. Thin Solid Films, 1987, 146:7581.

15. Haug F-J, Soderstrom T, Python M, Terrazzoni-Daudrix V, Niquille X, Ballif C. Development of micromorph tandem solar cells on flexible low-cost plastic substrates. Sol. Energ. Mater. Sol. Cell., 2009, 93:884-887.

16. Gemmer C, Schubert MB. Solar cell performance under different illumination conditions. Mater. Res. Soc. Symp. Proc., 2001, 664:A25.9.1.

17. Contreras MA, Egaas B, Ramanathan K, Hiltner J, Swartzlander A, Hasoon F, Noufi R. Progress toward 20\% efficiency in $\mathrm{Cu}(\mathrm{In}, \mathrm{Ga})$ $\mathrm{Se}_{2}$ polycrystalline thin-film solar cells. Prog. Photovoltaic Res. Appl., 1999, 7:311-316.

18. Kessler F, Herrman D, Powalla M. Approaches to flexible CIGS thin-film solar cells. Thin Solid Films, 2005, 480-481:491-498.

19. Herrmann D, Kessler F, Klemm U, Kniese R, Magorian-Friedlmeier T, Spiering S, Witte W, Powalla M. Flexible, monolithically integrated $\mathrm{Cu}(\mathrm{In}, \mathrm{Ga}) \mathrm{Se}_{2}$ thin-film solar modules. Mater. Res. Soc. Symp. Proc., 2005, 865:F15.1.1.

20. Hartmann M, Schmidt M, Jasenek A, Schock HW, Kessler F, Herz K, Powalla M. Flexible and light weight substrate for $\mathrm{Cu}(\mathrm{In}, \mathrm{Ga}) \mathrm{Se}_{2}$ solar cell and modules. Conference Record of the 28th IEEE Photovoltaic Specialists Conference, IEEE, New York, 2000, p. 638-639. 
21. Tiwari AN, Romeo A, Baetzner D, Zogg H. Flexible CdTe solar cells on polymer films. Prog. Photovoltaic Res. Appl., 2001, 9:211-215.

22. Dennler G, Forberich K, Ameri T, Waldauf C, Denk P, Brabec CJ, Hingerl K, Heeger AJ. Design of efficient organic tandem cells: on the interplay between molecular absorption and layer sequence. J. Appl. Phys., 2007, 102:123109-1 - 123109-6.

23. Brabec CJ. Organic photovoltaics: technology and market. Sol. Energ. Mater. Sol. Cell., 2004, 83:273-292.

24. Lagref JJ, Nazeeruddin MK, Graetzel M. Molecular engineering on semiconductor surfaces: design, synthesis and application of new efficient amphiphilic ruthenium photosensitizers for nanocrystalline $\mathrm{TiO}_{2}$ solar cells. Synth. Met., 2003, 138:333-339.

25. Chwang AB, Rothman MA, Mao SY, Hewitt RH, Weaver MS, Silvernail JA, Rajan K, Hack M, Brown JJ, Chu X, Moro L, Krajewski T, Rutherford N. Thin film encapsulated flexible organic electroluminescent displays. Appl. Phys. Lett., 2003, 83:413-415.

26. Hanak JJ. Monolithic solar cell panel of amorphous silicon. Sol. Energ., 1979, 23:145147.

27. Merz R, Adachi MM, Werner JH, Schubert MB. n-Situ series connection for thin film photovoltaic modules. Proc. of the $23 \mathrm{rd}$ European Photovoltaic Solar Energy Conference. D. Lincot, H. Ossenbrink and P. Helm eds., WIP Renewable Energies, Munich, 2008, p. 2411-2413.

28. Merz R. Method for producing seriesconnected solar cells and apparatus for carrying out the method. US patent application 2009/0017193 (2009).

29. Ishikawa Y, Schubert MB. Flexible protocrystalline silicon solar cells with amorphous buffer layer. Jpn. J. Appl. Phys., 2006, 45:6812-6822.

30. Koh J, Lee Y, Fujiwara H, Wronski CR, Collins RW. Optimization of hydrogenated amorphous silicon $\mathrm{p}-\mathrm{i}-\mathrm{n}$ solar cells with two- step i layers guided by real-time spectroscopic ellipsometry. Appl. Phys. Lett., 1998, 73:15261528.

31. Koch C, Ito M, Schubert MB. Lowtemperature deposition of amorphous silicon solar cells. Sol. Energ. Mater. Sol. Cell., 2001, 68:227-236.

32. Guha S, Yang J, Banerjee A, Yan B, Lord K. High quality amorphous silicon materials and cells grown with hydrogen dilution. Sol. Energ. Mater. Sol. Cell., 2003, 78:329-347.

33. Williamson DL. Nanostructure of a-Si:H and related materials by small-angle X-ray scattering. Mater. Res. Soc. Symp. Proc., 1995, 377:251-254.

34. Luysberg M, Hapke P, Carius R, Finger F. Structure and growth of $\mu \mathrm{c}-\mathrm{Si}: \mathrm{H}$ :Investigation by TEM and Raman spectroscopy on samples prepared at different plasma excitation frequencies. Phil. Mag., 1997, A75:31-37.

35. Houben L, Luysberg M, Hapke P, Carius R, Finger F, Wagner H. Structural properties of microcrystalline silicon in the transition from highly crystalline to amorphous growth. Phil. Mag., 1998, A77:1447-1452.

36. Koch C, Ito M, Schubert MB, Werner JH. Lowtemperature deposition of amorphous silicon based solar cells. Mater. Res. Soc. Symp. Proc., 1999, 557:749-754.

37. Losurdo M, Giangregorio M, Grimaldi A, Capezzuto P, Bruno G. A study of growth mechanism of microcrystalline thin silicon films deposited at low temperature by $\mathrm{SiF}_{4}-$ $\mathrm{H}_{2}$-He PECVD. Eur. Phys. J.Appl. Phys., 2004, 26:187-192.

38. Fejfar A, Mates T, Koch C, Rezek B, Svrcek V, Fojtık P, Stuchlırkova H, Stuchlık J, Kocka J. Microscopic aspects of charge transport in hydrogenated microcrystalline silicon. Mater. Res. Soc. Symp. Proc., 2001, 664:A16.1.

39. Meier J, Vallat-Sauvain E, Dubail S, Kroll U, Dubail J, Golay S, Feitknecht L, Torres P, Fay S, Fischer D, Shah A. Microcrystalline/ micronorth silicon thin-film solar cells prepared be VHF-GD technique. Sol. Energ. 
Mater. Sol. Cell., 2001, 66:73-84.

40. Shah AV, Meier J, Vallat-Sauvain E, Wyrsch N, Kroll U, Droz C, Graf U. Material and solar cell research in microcrystalline silicon. Sol. Energ. Mater. Sol. Cell., 2003, 78:469-491.

41. Schropp REI, Rath JK, Li H. Growth mechanism of nanocrystalline silicon at the phase transition and its application in thin film solar cells. J. Cryst. Growth, 2009, 311:760-764.

42. Hamma S, Roca i Cabarroca P. Lowtemperature growth of thick intrinsic and ultrathin phosphorous or boron-doped microcrystalline silicon films: Optimum crystalline fractions for solar cell applications. Sol. Energ. Mater. Sol. Cell., 2001, 69:217-239.

43. Alpuim P, Chu V, Conde JP. Amorphous and microcrystalline silicon films grown at low temperatures by radio-frequency and hot-wire chemical vapor deposition. J. Appl. Phys., 1999, 86:3812-3821.

44. Ito M, Koch C, Svrcek V, Schubert MB, Werner JH. Silicon thin film solar cells deposited under $80^{\circ} \mathrm{C}$. Thin Solid Films, 2001, 383:129-131.

45. Staebler DL, Wronski CR. Reversible conductivity changes in discharge produced amorphous Si. Appl. Phys. Lett., 1977, 31:292294.

46. Koch C, Ito M, Svrecek V, Schubert MB, Werner JH. Protocrystalline growth of silicon below $80^{\circ}$ C. Mater. Res. Soc. Symp. Proc., 2000, 609:A15.6.

47. Spear WE, LeComber PG. Substitutional doping of amorphous silicon. Solid State Comm., 1975, 17:1193-1196.

48. Alpuim P, Chu V, Conde JP. Electronic and structural properties of doped amorphous and nanocrystalline silicon deposited at low substrate temperatures by radio-frequency plasma-enhanced chemical vapor deposition. J. Vac. Sci. Tech., 2003, A21:1048-1054.

49. Ishikawa Y, Schubert MB. Protocrystalline silicon cells deposited at $110^{\circ} \mathrm{C}$ in nip and pin sequence. Proc. of the 20th European
Photovoltaic Solar Energy Conference. W. Palz, H. Ossenbrink and P. Helm eds., WIPRenewable Energies, Munich, 2005, p. 1525 1528.

50. Koh J, Ferlauto AS, Rovira PI, Wronski CR, Collins RW. Evolutionary phase diagrams for plasma-enhanced chemical vapor deposition of silicon thin films from hydrogen-diluted silane. Appl. Phys. Lett., 1999, 75:2286-2288. 